Article

\title{
Are the Blockchain-Based Patents Sustainable for Increasing Firm Value?
}

\author{
Horim Kim ${ }^{1}{ }^{\mathbb{D}}$, Jaeyoung Kim ${ }^{2, *} \mathbb{C}$, Kyungmyung Jang ${ }^{1} \mathbb{D}$ and Jaemin Han ${ }^{1}$ \\ 1 Korea University Business School, Korea University, Seoul 02841, Korea; tigerfo@korea.ac.kr (H.K.); \\ myeongsu@korea.ac.kr (K.J.); jaemin@korea.ac.kr (J.H.) \\ 2 Division of Convergence Business, Korea University, Sejong 30019, Korea \\ * Correspondence: korean4u@korea.ac.kr
}

Received: 27 January 2020; Accepted: 6 February 2020; Published: 26 February 2020

\begin{abstract}
Blockchain technology is changing conventional online transaction systems by eliminating payment gateway firms. The blockchain technology is highly attractive and has earned a lot of attention from investors and firms. To protect blockchain technology, firms acquire a patent of blockchain for enhancing the value of their blockchain technology. However, the sustainable value for a patent of blockchain has not been clearly explored. For this reason, our research attempted to explore the relationship between a patent of blockchain and firm value. We used a real options theory and built robust empirical tests based on United State Patents and Trademark Office (USPTO) data. We collected the patents of blockchains from 2014 to 2018 and matched financial data from the Compustat database. In total, we found 153 panel observations. Our results suggest that a firm's patent of blockchain originality and t-1 lagged effects for a firm's patent of blockchain generality are positively associated with firm value in general. In addition, the sustainable value for the patent of blockchain affects firms differently based on their industry. We found that the sustainable value for the patent of blockchain originality was positively and exclusively associated with the software industry, while the sustainable value for the patent of blockchain generality was positively and exclusively associated with the hardware industry.
\end{abstract}

Keywords: a patent of blockchain; market uncertainty; real options theory; empirical study for a patent of blockchain; firm value

\section{Introduction}

Online transaction systems between buyers and sellers are mostly constructed with centralized database systems with intermediary firms such as PayPal, Amazon Pay, and Apple Pay. The centralized database systems are an attractive target to hackers [1]. There have been major information security (INFOSEC) incidents, for example, Equifax had 145 million users' credit cards attacked in 2017, 3 billion Yahoo users' accounts were stolen in 2014, and 77 million Sony PlayStation Network users' accounts were hacked in 2011. To handle the INFOSEC incidents from centralized database systems, blockchain technology, which provides a decentralized ledger, has attracted public attention since Bitcoin was introduced in 2008 [2,3]. Blockchain technology is recognized as a disruptive innovation to firms because it changes the conventional business structure of online transaction systems [4,5]. By using blockchain technology, firms can build secure transaction systems and reduce costs from the intermediary firms $[1,6]$. This blockchain technology can be applied in various fields, such as healthcare, smart contracts, and banks, for reducing firm's transaction costs [3,7]. To protect the advantages of blockchain technology from imitators, firms can use patent protection for the blockchain technology [8]. From Figure A1, we can observe that firms' activity for patenting of blockchain increased dramatically from 2013 to 2017. The figure shows that two patents of blockchain were granted in 2013 and 252 patents 
of blockchain were granted in 2017. Based on the phenomena of increasing the patents of blockchain, there are many firms attempting to develop blockchain technology and protect their innovations by using patents. To address the phenomena of increasing patents of blockchain, we explored the prior research that related to firms' patents and firm value. Prior research focused on the value of patents and found that firms' patents are positively associated with the firms' market values in stabilized markets such as software, information technology, the semiconductor industry, and the FinTech industry [9-13]. Although the prior research has propounded the positive relationship between a firm's patents and its value, the patents of blockchain are different in comparison with conventional patents. First, the value of the patent of blockchain has not been clearly explored in terms of how firms can enhance their firm value by using the patent of blockchain. Second, the investment returns for the patent of blockchain are not clear. Although firms keep developing blockchain technology and acquiring patents of blockchain, the effects of the patents of blockchain have not been explored. For this reason, one question arises about whether or not the patent of blockchain is sustainable for increasing firm value. To fill the research gap of the relationship between a patent of blockchain and a firm's market valuation, we pose this research question: Does a patent of blockchain affect firm value? To answer this research question, we collected the patents of blockchain from 2014 to 2018 in the United State Patents and Trademark Office (USPTO) database and matched them to financial data from the Compustat database. In total, we found 153 panel observations. Based on the collected data, we built various panel regression tests and subsampling tests for exploring the relationship between a patent of blockchain and firm value. Specifically, we used real options investment theory to build on the prior research and empirically examine factors of market valuation by using the patents of blockchain.

\section{Related Literature}

\subsection{Patents Value and a Patent of Blockchain Value}

In competitive market conditions, firms keep developing their products and services using innovative technology. To assure the advantages of innovative technology, firms need to protect their innovative technologies from imitators. Patents are suitable options that provide legal protections for a firm's innovations [14-16]. From this perspective, the prior research presents two major advantages of acquiring the patents. The first advantage is protection of innovative technology from competitors. From the first advantage, firms can deploy patents strategically based on the importance of the patents for maximizing a firm's revenues [17]. Firms can deploy defensive strategies if the patents describe a firm's core innovative technologies, allowing them to protect their core innovations [18]. In contrast to defensive strategies, firms can take offensive strategies if the patents do not describe the core technologies in their business, but they still want to protect themselves from imitations by other market participants. The second advantage is that firms can gain extra revenue by licensing the patents and attracting investors by using the patents. For start-up firms, patents can attract venture capital firms by enhancing a firm's return on investment by presenting their innovative technology [14]. To mature firms, patents can increase a firm's additional revenue streams through licensing of the patents [15]. The value of a firm's patents can be related to firm performance (e.g., net income, Tobin's q, and market value) by increasing a firm's sales and market valuation [10,11,19-21]. Specifically, extensive prior research has focused on finding a positive relationship between patents and firm value. The findings suggest that a firm's patents can positively affect its value $[11,22,23]$. However, patents of blockchain have not been explored in prior research. To fill this research gap, we used real options theory for exploring the relationship between a firm's patent of blockchain and the firm's market valuation.

\subsection{A Patent of Blockchain and the Real Options Theory}

A real options theory proposes that uncertainty of market revenues could reduce current investments by decreasing the value of future market incentives $[11,24,25]$. From the real options perspective, patents can guarantee a firm's market predominance by protecting the firm's innovative 
technologies from imitators [11,25]. This firm's management decision of investing patents can reduce market uncertainty that increases current investments. By using the real options theory, prior researchers found that patents are positively associated with a firm's Tobin's q [11,19,20].

Although the prior research propounds the positive relationship between patents and firm value, a patent of blockchain could affect to firm value differently because the investment return of blockchain adoption is still not clear [26]. In addition, the market of blockchain just began and the effects of the patent of blockchain on firms have not been clearly explored [8,27,28]. Although many prior researchers have propounded that many firms try to adopt the blockchain technology for cost saving and gaining sustainable competitive advantages, firms have many upcoming challenges (i.e., security, scalability, legal and regulatory, privacy, latent technology development) in the FinTech industry $[12,13,29]$. From this perspective, we argue that the patent of blockchain needs to have a more clear approach for understanding the relationship between the patent of blockchain and market uncertainty in real option theory. If the value for the patent of blockchain is sustainable enough to increase firm value, the effects for the patent of blockchain are as positively associated with firm value as conventional patents. To find out the relationship between the patent of blockchain and market valuation based on market uncertainty, we developed our hypotheses as shown in Figure 1.

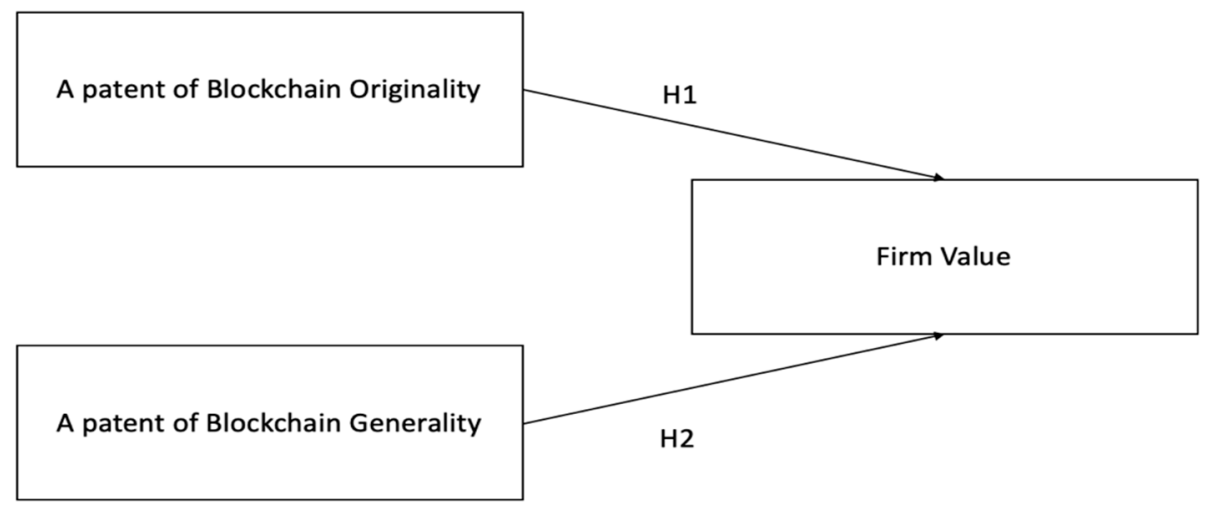

Figure 1. Research model.

\section{Hypothesis Development}

\subsection{A Patent of Blockchain Originality}

In competitive market conditions, development of certain technology is important to enhance a firm's productivity and efficiency. Blockchain technology is a new emerging technology and many firms develop blockchain technology for technological advantages. The firm's development of blockchain technology can be cited from other firms that proceed to develop other technologies. For example, if a patent of blockchain for firm A is cited from firm B and C, the patent of blockchain originality is increased. In this case, a cited patent of blockchain for firm A can be a useful technology and other firms should refer to the patent of blockchain A for creating their blockchain technology. For this reason, the cited patent of blockchain can present technology of originality [30]. The patent of blockchain originality can reduce market uncertainty for assuring technological predominance. From this perspective, reduced market uncertainty for the patent of blockchain originality can increase $s$ firm's value. We derive our first hypothesis.

Hypothesis 1. A patent of blockchain originality is positively associated with firm value.

\subsection{A Patent of Blockchain Generality}

Developing blockchain technology can be associated with other technologies such as information security, hardware, and software. The combining of different technologies into developing blockchain 
can increase applicability for the patent of blockchain in various industries such as banks, healthcare, and manufacturing. For example, if firm A cited three patents from firm B, C, and D, the patent of blockchain generality is high. If the patent of blockchain generality is high, the patent of blockchain can be highly converged with other technologies. In this perspective, the patent of blockchain generality can reduce market uncertainty for increasing a firm's usability of the patent in various markets by increasing the firm's sustainability. From this perspective, we derive our second hypothesis.

Hypothesis 2. A patent of blockchain generality is positively associated with firm value.

\section{Data and Empirical Model}

\subsection{Data Collection}

For analyzing a patent of blockchain and firm value, we collected publicly available archival data from the United State Patents and Trademark Office (USPTO) and Compustat database for matching financial data. The data collection followed two steps. First, we collected total patents of blockchain data by keyword searching (e.g., blockchain, blockchain technology) in the USPTO database from 2013 to 2019. In total, we collected 784 patents of blockchain from the USPTO. We set the patents of blockchain year by the patents' filing year for handling long lags between the granted year and application year [11,31]. Second, we collected each firm's financial data that are listed in the patents of blockchain.

Specifically, we collected firm's sales, employment, market value, assets, advertisement expense, research and development expense (R\&D), and global industry classification standard (GICS) codes from Wharton Research Data Services (Compustat). After matching the financial data, we got 153 panel observations from 2014 to 2018. To minimize firm-level heterogeneity, we focused on the information technology (IT) industry as more than $50 \%$ of blockchain patents are in the IT industry. Specifically, we use the GICS code that contains three IT subindustries because GICS codes are better at explaining stock market valuation than standard industrial classification codes [32]. Finally, we got three IT subindustries and the 153 observations as shown in Table 1.

Table 1. Total sample.

\begin{tabular}{ccc}
\hline GICS Code & Title & Observations \\
\hline 4510 & Software and Services & 98 \\
4520 & Technology Hardware and Equipment & 48 \\
4530 & Semiconductors and Semiconductor Equipment & 7 \\
\hline
\end{tabular}

\subsection{Variables}

\subsubsection{Dependent Variables}

To analyze our hypotheses, we used Tobin's q as our dependent variable. The Tobin's q can capture a firm's financial performance in the capital market that has been used in prior research [11,33-35]. We measured the Tobin's q as discussed in prior research such as Bharadwaj et al. (1999) and Chung et al. (2019). The Tobin's q is calculated by Equation (1),

$$
\text { Tobin's q }=(\mathrm{MVE}+\mathrm{PS}+\mathrm{DEBT}) / \mathrm{TA}
$$

where:

MVE $=($ Closing price of share at the end of the financial year $) *($ Number of common shares outstanding $)$; PS = Liquidating value of the firm's outstanding preferred stock;

DEBT $=($ Current liabilities - Current assets $)+($ Book value of inventories $)+($ Long term debt $)$, $\mathrm{TA}=$ Book value of total assets. 


\subsubsection{Independent Variables}

We measured a patent of blockchain originality and generality by using the patent's citation information. We used firm's accumulated patent of blockchain citations made for the patent's originality and used the firm's accumulated cited patents in the patent of blockchain for the patent generality. For example, if firm A cited three patents from firm B or C, the patent of blockchain generality is higher than if none were cited. Additionally, if firm A's patent of blockchain cited from firm B, C, and D, the patent of blockchain originality is higher than if none were cited.

\subsubsection{Control Variables}

In this study, we added control variables that are not included in explanatory variables. The control variables present the firm's characteristics that could affect its Tobin's q. We used employ, R\&D intensity, advertising intensity, market share, and industry Tobin's q for controlling the firm-specific characteristics and industry-specific characteristics. Employ presents the proxy of firm size by using the firm's total employees. Firms with a large number of employees can create more value than other firms [22,36]. R\&D Intensity controls a firm's investment for creating and enhancing the firm's products and services. Firm's large investment R\&D intensity can create more effective production and create more innovative products that increase firm value [37,38]. Advertising intensity controls firm's investment for selling more products and enhancing firm's public relations [11,35,39]. Finally, we included the firm's market share and industry Tobin's q to control for the firm's market share of products and industry growth of Tobin's q [11,35].

Table 2 summarizes all of the variables' definitions and sources of the variables for further analyses. We also include transformation of the variables.

Table 2. Variable description.

\begin{tabular}{|c|c|c|c|}
\hline Variables & Description & Source & Transformation \\
\hline \multicolumn{4}{|l|}{ Dependent Variable } \\
\hline Tobin's q & $\begin{array}{c}\text { Tobin's q measured below equation: } \\
\text { Tobin's q = (MVE + PS + DEBT)/TA } \\
\text { (See Equation one in Section 4.2.1) } \\
\text { as in Bharadwaj, Bharadwaj, and Konsynski [35] } \\
\text { and Chung, Animesh, Han, and Pinsonneault [11] }\end{array}$ & $\begin{array}{l}\text { Wharton } \\
\text { Database }\end{array}$ & $\begin{array}{l}\text { Napierian } \\
\text { Logarithm }\end{array}$ \\
\hline \multicolumn{4}{|l|}{ Independent Variables } \\
\hline $\begin{array}{l}\text { A Patent of Blockchain } \\
\text { Originality }\end{array}$ & $\begin{array}{c}\text { Accumulated a patent of blockchain citation counts } \\
\text { that made citations }\end{array}$ & USPTO & $\begin{array}{l}\text { Napierian } \\
\text { Logarithm }\end{array}$ \\
\hline $\begin{array}{l}\text { A Patent of Blockchain } \\
\text { Generality }\end{array}$ & $\begin{array}{l}\text { Accumulated a patent of blockchain citation counts } \\
\text { that cited other patents for patenting }\end{array}$ & USPTO & $\begin{array}{l}\text { Napierian } \\
\text { Logarithm }\end{array}$ \\
\hline \multicolumn{4}{|l|}{ Control Variables } \\
\hline Employ & Total employees & $\begin{array}{l}\text { Wharton } \\
\text { Database }\end{array}$ & $\begin{array}{l}\text { Napierian } \\
\text { Logarithm }\end{array}$ \\
\hline R\&D Intensity & Firm's R\&D expenses to sales & $\begin{array}{l}\text { Wharton } \\
\text { Database }\end{array}$ & $\begin{array}{l}\text { Napierian } \\
\text { Logarithm }\end{array}$ \\
\hline Advertising Intensity & Firm's advertising expenses to sales & $\begin{array}{l}\text { Wharton } \\
\text { Database }\end{array}$ & $\begin{array}{l}\text { Napierian } \\
\text { Logarithm }\end{array}$ \\
\hline Market Share & $\begin{array}{l}\text { Sales divided by industry sales based on GICS } \\
\text { four-digit code } \\
\text { (Sales/Average Sales at the same GICS code) }\end{array}$ & $\begin{array}{l}\text { Wharton } \\
\text { Database }\end{array}$ & $\begin{array}{l}\text { Napierian } \\
\text { Logarithm }\end{array}$ \\
\hline Industry Tobin's q & $\begin{array}{l}\text { Tobin's q divided by industry Tobin's q on GICS } \\
\text { four-digit code } \\
\text { (Tobin's q/average Tobin's q at the four-digit GICS } \\
\text { code level) }\end{array}$ & $\begin{array}{l}\text { Wharton } \\
\text { Database }\end{array}$ & $\begin{array}{l}\text { Napierian } \\
\text { Logarithm }\end{array}$ \\
\hline
\end{tabular}




\subsection{Descriptive Statistics}

Our sample contained a total of 153 observations. We took log transformations for all variables, as prior research used $[11,35]$. The log transformation allowed us to analyze our hypotheses for a more intuitive interpretation of the regression coefficients based on elasticity. We report our descriptive statistics of all variables in Table 3. We also present a correlation matrix to find notable correlations related to our research in Table 4.

Table 3. Descriptive statistics.

\begin{tabular}{cccccc}
\hline Variables & Observation & Mean & Std. Dev. & Min & Max \\
\hline Tobin's q & 153 & 0.950 & 0.481 & -0.084 & 1.741 \\
A Patent of Blockchain Originality & 153 & 0.135 & 0.516 & 0 & 3.871 \\
A Patent of Blockchain Generality & 153 & 0.780 & 1.690 & 0 & 7.264 \\
Employ & 153 & 3.065 & 1.662 & 0.016 & 6.131 \\
R\&D Intensity & 153 & 2.496 & 0.805 & 0.839 & 6.094 \\
Advertising Intensity & 153 & 0.995 & 0.714 & 0.112 & 5.376 \\
Market Share & 153 & 0.076 & 0.134 & 0.001 & 0.670 \\
Industry Tobin's q & 153 & 1.244 & 0.409 & 0.970 & 2.180 \\
\hline
\end{tabular}

Table 4. Correlation matrix.

\begin{tabular}{lccccccccc}
\hline & Variables & $\mathbf{1}$ & $\mathbf{2}$ & $\mathbf{3}$ & $\mathbf{4}$ & $\mathbf{5}$ & $\mathbf{6}$ & $\mathbf{7}$ & $\mathbf{8}$ \\
\hline 1 & Tobin's q & 1.000 & & & & & & & \\
2 & A Patent of Blockchain Originality & 0.102 & 1.000 & & & & & & \\
3 & A Patent of Blockchain Generality & 0.112 & 0.575 & 1.000 & & & & & \\
4 & Employ & -0.203 & 0.198 & 0.241 & 1.000 & & & & \\
5 & R\&D Intensity & 0.312 & -0.138 & -0.006 & -0.411 & 1.000 & & & \\
6 & Advertising Intensity & 0.165 & -0.042 & -0.109 & -0.377 & 0.449 & 1.000 & & \\
7 & Market Share & -0.099 & 0.054 & 0.116 & 0.579 & -0.083 & -0.060 & 1.000 & \\
8 & Industry Tobin's q & 0.049 & -0.114 & -0.165 & 0.011 & -0.021 & -0.113 & 0.041 & 1.000 \\
\hline
\end{tabular}

We first present our sample's characteristics based on employ and R\&D intensity variables. The mean of the employ variable was 3.065 and the standard deviation was 1.662 . The mean of R\&D intensity was 2.496 and standard deviation was 0.805 . These results may indicate that our sample firm's size was quite large and its R\&D intensity was relatively high. Second, the standard deviation for a patent of blockchain originality and a patent of blockchain generality was relatively large. In particular, based on Figures 2 and 3, which present sample distributions based on four-digit GICS codes (4510: software and services, 4520: technology hardware and equipment and 4530: semiconductors and semiconductor equipment), the software and services industry had the greatest number for a patent of blockchain originality, as shown in Figure 2. This indicates that the originality of blockchain technology converged in the software and services industry, and the patent of blockchain originality is highly distributed in the software and services industry. Similarly, In Figure 3, the greatest number for a patent of blockchain generality was in the software and services industry from 2014 to 2017. However, the greatest number for a patent of blockchain generality changed to the technology hardware and equipment industry in 2018. This could indicate an increase in value based on a firm's strategy of acquiring the patents of quite diverse blockchains, and the value of patent originality and generality can affect the value of firms differently based on industry characteristics. To acquire the insights of industry differences between the patent originality and generality, we built subsampling tests for identifying whether the patent of blockchain originality and generality affect firms' values differently based on the industry they are in or not. Finally, we present a variable inflation factor (VIF) for all independent variables to check multicollinearity on Tobin's q in Table 5. The VIF results show that all independent variables' VIF values were not higher than $5[40,41]$. The highest correlation was 0.579 (Table 4), which was lower than the critical threshold of 0.7 as prior research has discussed [42,43]. 
Based on the results, the independent variables in our regression models based on Tobin's q had no multicollinearity issues.

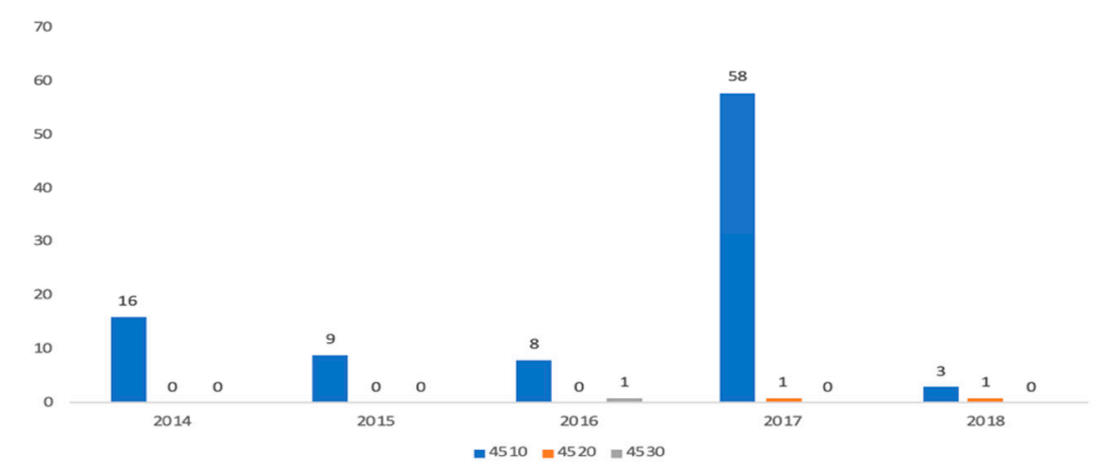

Figure 2. Sample distribution for the patent of blockchain originality in the United States.

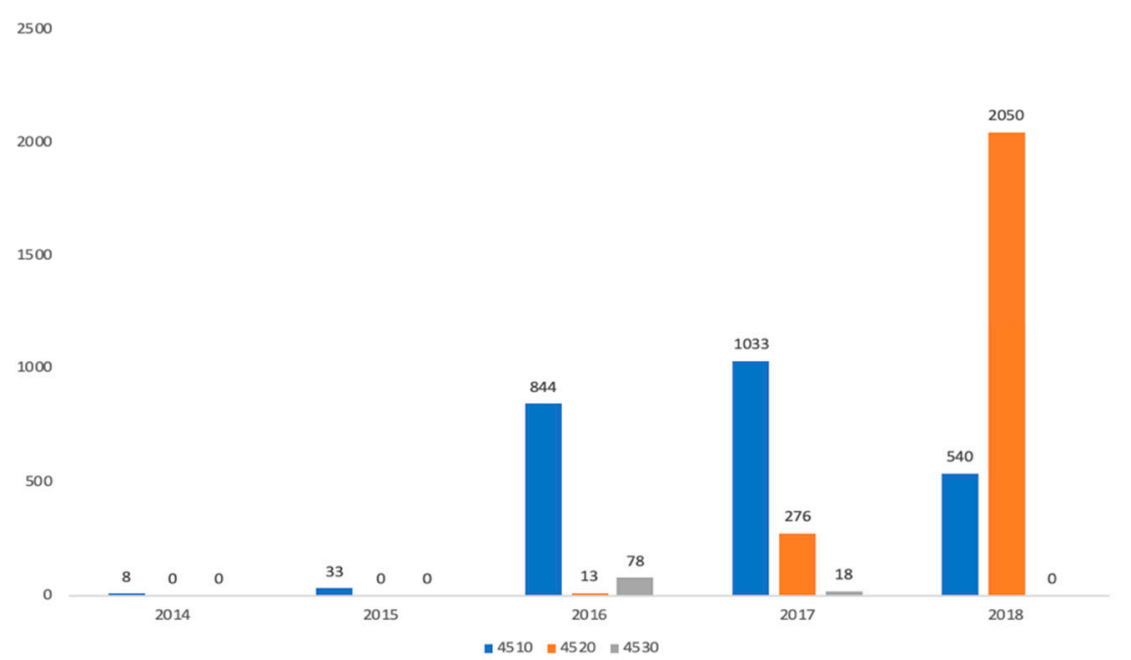

Figure 3. Sample distribution for the patent of blockchain generality in the United States.

Table 5. Variance inflation factor results.

\begin{tabular}{ccc}
\hline Variables & VIF & 1/VIF \\
\hline A Patent of Blockchain Originality & 1.57 & 0.638 \\
A Patent of Blockchain Generality & 1.64 & 0.611 \\
Employ & 2.15 & 0.465 \\
R\&D Intensity & 1.47 & 0.681 \\
Advertising Intensity & 1.41 & 0.708 \\
Market Share & 1.63 & 0.615 \\
Industry Tobin's q & 1.05 & 0.949 \\
\hline
\end{tabular}

\subsection{Regression Tests}

In our empirical specifications, we built a similar panel regression model as that which has been used widely in prior research. To test the relationship between a patent of blockchain and firm value, we set our estimation model as Equation (2).

$$
\begin{aligned}
\text { Tobin's }_{(i, t)}=\beta_{0} & +\beta_{1} \text { A Pantent of Blockcain Originality } y_{i, t} \\
& +\beta_{2} \text { A Pantent of Blockcain Generality } y_{i, t}+\beta_{3} \text { Employ }_{i, t} \\
& +\beta_{4} \text { R\&D Intensity } y_{i, t}+\beta_{5} \text { Adverti } \sin g \text { Intensity } y_{i, t} \\
& +\beta_{6} \text { Market Share } i, t+\beta_{7} \text { Industry Tobin's } q_{i, t}+\text { Firm Dummy } \\
& + \text { Year Dummy }+\varepsilon_{i, t}
\end{aligned}
$$


where firm $i$ is in year $t$. We took the natural logarithm of all variables in the estimation model for controlling skewness. We included fixed effects models and random effects models based on the consideration of firm and time dummies. To select more appropriate models, we conducted the Hausman test to check whether the error terms in the regressions were correlated with our explanatory variables or not [44]. The Hausman test results showed Prob $>\chi^{2}=0.000$, which rejects the null hypothesis that errors are not correlated with our explanatory variables. In our empirical estimations, fixed effects models are more efficient estimators based on the Hausman test results. Although, the fixed effects models control unobserved heterogeneity based on firm dummy and year dummy, serial correlation could create biases of the standard errors that could cause the coefficient to be smaller in our panel regressions $[11,45,46]$. To handle the serial correlation, we conducted a Wooldridge test to check whether our estimations had serial correlation or not. The Wooldridge test results presented $\mathrm{F}=3.633$ and $p<0.067$, which cannot reject the null hypothesis of no serial correlation. Thus, we adopted a fixed effects models as our main model (Model 4) for further analyses. We reported the regression results of random and fixed effects models to check and compare the consistency of variables' effects on Tobin's q, as shown in Table 6, and fixed effects models of the lagged effects for blockchain patent generality, as shown in Table 7.

Table 6. A patent of blockchain on Tobin's q regressions results.

\begin{tabular}{|c|c|c|c|c|}
\hline $\begin{array}{c}\text { Variables } \\
\text { Dependent Variable: Log (Tobin's q) }\end{array}$ & Model (1) & Model (2) & Model (3) & Model (4) \\
\hline A Patent of Blockchain Originality & & $\begin{array}{c}0.122 \\
(0.097)\end{array}$ & & $\begin{array}{l}0.059 * * \\
(0.031)\end{array}$ \\
\hline A Patent of Blockchain Generality & & $\begin{array}{c}0.026 \\
(0.031)\end{array}$ & & $\begin{array}{c}-0.008 \\
(0.0131)\end{array}$ \\
\hline Employ & $\begin{array}{l}-0.017 \\
(0.034)\end{array}$ & $\begin{array}{l}-0.034 \\
(0.033)\end{array}$ & $\begin{array}{l}0.00214 \\
(0.0784) \\
\end{array}$ & $\begin{array}{l}-0.006 \\
(0.0785)\end{array}$ \\
\hline R\&D Intensity & $\begin{array}{l}0.166^{* * *} \\
(0.055)\end{array}$ & $\begin{array}{l}0.163^{* * *} \\
(0.058)\end{array}$ & $\begin{array}{l}-0.212 * \\
(0.117)\end{array}$ & $\begin{array}{l}-0.224 * \\
(0.119)\end{array}$ \\
\hline Advertising Intensity & $\begin{array}{c}0.013 \\
(0.066)\end{array}$ & $\begin{array}{c}0.015 \\
(0.069)\end{array}$ & $\begin{array}{l}0.210 * \\
(0.111)\end{array}$ & $\begin{array}{l}0.226 * * \\
(0.112)\end{array}$ \\
\hline Market Share & $\begin{array}{l}-0.132 \\
(0.233)\end{array}$ & $\begin{array}{l}-0.093 \\
(0.237)\end{array}$ & $\begin{array}{c}0.410 \\
(1.311)\end{array}$ & $\begin{array}{c}0.534 \\
(1.320)\end{array}$ \\
\hline Industry Tobin's q & $\begin{array}{l}-0.121 \\
(0.143)\end{array}$ & $\begin{array}{l}-0.074 \\
(0.147)\end{array}$ & $\begin{array}{c}-0.273^{* * *} \\
(0.076)\end{array}$ & $\begin{array}{c}-0.280^{* * *} \\
(0.080)\end{array}$ \\
\hline Constant & $\begin{array}{l}0.877^{* *} \\
(0.357)\end{array}$ & $\begin{array}{l}0.830 * * \\
(0.354)\end{array}$ & $\begin{array}{c}1.992 * * * \\
(0.402)\end{array}$ & $\begin{array}{c}2.013 * * * \\
(0.406)\end{array}$ \\
\hline Firm Dummy & No & No & Yes & Yes \\
\hline Year Dummy & Yes & Yes & Yes & Yes \\
\hline Observations & 153 & 153 & 153 & 153 \\
\hline R-squared & 0.126 & 0.160 & 0.286 & 0.304 \\
\hline
\end{tabular}


Table 7. Lagged effects for a patent of blockchain generality on Tobin's q regressions results.

\begin{tabular}{|c|c|c|}
\hline $\begin{array}{c}\text { Variables } \\
\text { Dependent Variable: Log (Tobin's q) }\end{array}$ & Model (5) & Model (6) \\
\hline A Patent of Blockchain Originality & & $\begin{array}{l}0.069^{* * *} \\
(0.004)\end{array}$ \\
\hline A Patent of Blockchain Generality ${ }_{t-1}$ & & $\begin{array}{l}0.018^{*} \\
(0.005)\end{array}$ \\
\hline Employ & $\begin{array}{l}-0.055 \\
(0.072)\end{array}$ & $\begin{array}{l}-0.066 \\
(0.066)\end{array}$ \\
\hline R\&D Intensity & $\begin{array}{c}0.415 \\
(0.316)\end{array}$ & $\begin{array}{c}0.401 \\
(0.309)\end{array}$ \\
\hline Advertising Intensity & $\begin{array}{l}-0.107 \\
(0.086)\end{array}$ & $\begin{array}{l}-0.101 \\
(0.085)\end{array}$ \\
\hline Market Share & $\begin{array}{c}0.425 \\
(1.575)\end{array}$ & $\begin{array}{c}0.440 \\
(1.565)\end{array}$ \\
\hline Industry Tobin's q & $\begin{array}{c}0.579 \\
(0.348)\end{array}$ & $\begin{array}{c}0.482 \\
(0.349)\end{array}$ \\
\hline Constant & $\begin{array}{c}0.695 \\
(0.585)\end{array}$ & $\begin{array}{c}0.807 \\
(0.569)\end{array}$ \\
\hline Firm Dummy & Yes & Yes \\
\hline Year Dummy & Yes & Yes \\
\hline Observations & 130 & 130 \\
\hline R-squared & 0.284 & 0.293 \\
\hline
\end{tabular}

\subsection{Regression Results}

We present four models for regression tests in Table 6 to consider the unobservable effects to firm and year-specific effects. Model (1) and model (2) are random effects models that include only control variables in the model (1) and all variables in model (2). Model (3) and model (4) are fixed effects models that include only control variables in the model (3) and all variables in model (4). From the Hausman test, we analyzed our hypotheses by using the main model (4). The first results are related to our hypothesis 1 and second results are related to our hypothesis 2 . First, the estimation results in our main model (4) show that a patent of blockchain originality was positively associated with Tobin's q. Specifically, a 1\% increase of a patent of blockchain originality was significantly associated with a $0.059 \%$ increase in firm's Tobin's $q(p<0.05)$. Second, the estimation results in our main model (4) show that a patent of blockchain generality was not significantly associated with Tobin's q. The results presented do not support our hypothesis 2 . However, the $\mathrm{t}-1$ lagged effects for the patent of blockchain generality were positively and significantly associated with Tobin's q in model (6) from Table 7 . Specifically, $1 \%$ increase of $\mathrm{t}-1$ lagged patent of blockchain generality was significantly associated with a $0.018 \%$ increase in firm's Tobin's q $(p<0.10)$. Based on the results, the effects for the patent of blockchain generality were not directly evident in Tobin's q. The results indicate that the combination of different technologies from other patents for creating the patent of blockchain need time to increase firm value.

\subsection{Subsampling Tests}

The sample distribution for the patent originality and generality were highly associated with the software industry and hardware industry, and the effects of the patent originality and generality on 
firm value could present different results for each industry. To analyze the industry differences on firm value, we set our subsampling equation models as Equation (3).

$$
\begin{aligned}
\text { Tobin's } q_{(i, t)}=\beta_{0} & +\beta_{1} \text { A Pantent of Blockcain Originality } y_{i, t} \\
& +\beta_{2} \text { A Pantent of Blockcain Generality } y_{i, t}+\beta_{3} \text { Employ }_{i, t} \\
& +\beta_{4} \text { R\&D Intensity } y_{i, t}+\beta_{5} \text { Advertising Intensity } y_{i, t}+\text { Firm Dummy } \\
& + \text { Year Dummy }+\varepsilon_{i, t}
\end{aligned}
$$

where firm $i$ is in year $t$. We took the natural logarithm of all variables in the estimation model for controlling skewness. We included fixed effects models and random effects models based on consideration of firm and time dummies. In the subsampling analysis, we only included firm-specific control variables. We divided the sample based on four-digit GICS codes. If the sample had 4510 GICS code (software and services), we included the sample into software industry. Otherwise, the 4520 GICS code (technology hardware and equipment) and the 4530 GICS code (semiconductors and semiconductor equipment) were included in the hardware industry.

\subsection{Subsampling Test Results}

We present two models for subsampling tests in Table 8 to consider the unobservable effects to firm and year-specific effects. First, the estimation results in the software industry from model (7) show that a patent of blockchain originality was positively associated with Tobin's q. Specifically, $1 \%$ increase of a patent of blockchain originality was significantly associated with a $0.094 \%$ increase in firm's Tobin's $q(p<0.05)$. However, the patent of blockchain generality was not significantly associated with Tobin's q. This indicates that the originality of blockchain technology converged in the software industry and the effects of patent of blockchain originality are highly related to increases in firm value in the software industry.

Table 8. Subsampling results on software industry and hardware industry.

\begin{tabular}{ccc}
\hline $\begin{array}{c}\text { Variables } \\
\text { Dependent Variable: Log (Tobin's q) }\end{array}$ & $\begin{array}{c}\text { Model (7) } \\
\text { Software Industry }\end{array}$ & $\begin{array}{c}\text { Model (8) } \\
\text { Hardware Industry }\end{array}$ \\
\hline A Patent of Blockchain Originality & $0.094^{* *}$ & -0.316 \\
$(0.053)$ & $(0.296)$ \\
\hline A Patent of Blockchain Generality & -0.031 & $0.051^{* *}$ \\
& $(0.0229)$ & $(0.006)$ \\
\hline Employ & 0.023 & -0.044 \\
& $(0.152)$ & $(0.0154)$ \\
\hline R\&D Intensity & -0.129 & $0.092^{* *}$ \\
& $(0.151)$ & $(0.0182)$ \\
\hline \multirow{2}{*}{ Advertising Intensity } & 0.169 & -0.128 \\
\hline Constant & $(0.149)$ & $0.0938)$ \\
\hline Firm Dummy & $1.142^{* *}$ & $(0.129)$ \\
\hline Year Dummy & $(0.474)$ & Yes \\
\hline Observations & Yes & Yes \\
\hline R-squared & Yes & 55 \\
\hline$* 05$, robust standard errors clustered by firms for fixed effects.
\end{tabular}

Vice versa, the patent of blockchain generality was positively associated with Tobin's q in the hardware industry, as can be seen from model (8). Specifically, a 1\% increase of a patent of blockchain originality was significantly associated with a $0.051 \%$ increase in firms' Tobin's q $(p<0.05)$. This 
indicates that the generality of blockchain technology converged in the hardware industry and the effects of patent of blockchain generality is highly related to an increase in firm value in the hardware industry.

\section{Robustness Checks}

Our main model (4) presents efficient estimators for controlling the unobservable heterogeneity of firm and year-specific effects by using firm and year dummy variables. Even though the estimator provides accurate results, there is the possibility of endogeneity between explanatory variables and the dependent variable $[11,22,47]$. For example, a firm's decision to acquire a patent of blockchain could be influenced by firm value. To control the potential endogeneity, prior researchers have used a lagged dependent variable in the regressions $[48,49]$. Even the lagged dependent variable may control the endogeneity and the results of estimation could be inconsistent for mean and standard deviations because a fixed effects model assumes that the error terms are not serially correlated and independent variables are not exogenous [49,50]. For this reason, prior research has used dynamic panel models by using a generalized method of moments (GMM) estimator proposed by Arellano and Bover [51] and Blundell and Bond [52]. We built the a GMM system that produces consistent estimators of coefficients by first calculating differences in our estimation model and then using $\mathrm{t}-1$ lagged dependent variables as instrumental variables to control the endogeneity. We conducted a two-step GMM to check the appropriate sets of instrumental variables by considering heteroscedasticity and autocorrelation of the error terms. We used the Arellano-Bond test to consider autocorrelation and the Hansen test to consider overidentifying restrictions. The Hansen test is more robust than the Sargan test for the checking overidentifying restrictions because the Hansen test considers heteroscedasticity for the overidentifying restrictions [53,54]. We present two GMM models in Table 9. Model (9) is a system GMM model that included only the effects of control variables on Tobin's q. Model (10) is the full system GMM model that included all variables on Tobin's q. The results of the Arellano-Bond test for zero correlation in the first-differenced errors in models (9) and (10) rejected the null hypothesis and could not reject the second-differenced errors at a significant level $(p<0.05)$. The results of testing overidentification using the Hansen test presented in models (9) and (10) could not reject the null hypothesis. We confirmed our instrumental variables were valid based on the Arellano-Bond test and Hansen test. From the results of model (10), we found consistent effects of our explanatory variables on Tobin's q by considering endogeneity. 
Table 9. A patent of blockchain on Tobin's q GMM results.

\begin{tabular}{|c|c|c|}
\hline $\begin{array}{c}\text { Variables } \\
\text { Dependent Variable: Log (Tobin's q) }\end{array}$ & Model (9) & Model (10) \\
\hline A Patent of Blockchain Originality & & $\begin{array}{l}0.088 * * \\
(0.039)\end{array}$ \\
\hline A Patent of Blockchain Generality & & $\begin{array}{l}-0.012 \\
(0.009)\end{array}$ \\
\hline Employ & $\begin{array}{c}0.056 \\
(0.043)\end{array}$ & $\begin{array}{c}0.020 \\
(0.048) \\
\end{array}$ \\
\hline R\&D Intensity & $\begin{array}{l}-0.096 \\
(0.093)\end{array}$ & $\begin{array}{l}-0.025 \\
(0.083)\end{array}$ \\
\hline Advertising Intensity & $\begin{array}{c}0.156 \\
(0.118)\end{array}$ & $\begin{array}{c}0.023 \\
(0.121)\end{array}$ \\
\hline Market Share & $\begin{array}{l}-0.254 \\
(0.315)\end{array}$ & $\begin{array}{l}-0.065 \\
(0.370)\end{array}$ \\
\hline Industry Tobin's q & $\begin{array}{l}0.383^{* * *} \\
(0.061)\end{array}$ & $\begin{array}{l}0.426^{* * *} \\
(0.112)\end{array}$ \\
\hline Constant & $\begin{array}{l}-0.304^{* * * *} \\
(0.084)\end{array}$ & $\begin{array}{l}-0.319 * * \\
(0.128)\end{array}$ \\
\hline Model fit & $\begin{array}{l}\text { Wald } x^{2}(6)=1061.690 \\
\text { Prob }>x^{2}=0.000\end{array}$ & $\begin{array}{c}\text { Wald } x^{2}(8)=1680.820 \\
\text { Prob }>x^{2}=0.000\end{array}$ \\
\hline Hansen test of overidentifying restrictions & $\begin{array}{c}x^{2}(23)=23.300 \\
\text { Prob }>x^{2}=0.443\end{array}$ & $\begin{array}{c}x^{2}(21)=23.820 \\
\text { Prob }>x^{2}=0.302\end{array}$ \\
\hline Arellano-Bond test for AR (1) & $\begin{array}{l}\text { First order } \mathrm{z}=-2.500 \\
\qquad(p=0.012)\end{array}$ & $\begin{array}{l}\text { First order } \mathrm{z}=-2.360 \\
\quad(p=0.018)\end{array}$ \\
\hline Arellano-Bond test for AR (2) & $\begin{array}{l}\text { Second order } \mathrm{z}=1.870 \\
(p=0.062)\end{array}$ & $\begin{array}{l}\text { Second order } \mathrm{z}=1.660 \\
(p=0.097)\end{array}$ \\
\hline Lagged Variable & $\begin{array}{l}0.850 * * * \\
(0.0625)\end{array}$ & $\begin{array}{l}0.870 * * * \\
(0.0656)\end{array}$ \\
\hline Observations & 128 & 128 \\
\hline
\end{tabular}

\section{Discussion}

Using the real options theory and the empirical test for a patent of blockchain originality and generality on firm value, we explored the relationship between a firm's patent of blockchain and firm value. Specifically, we used a patent of blockchain originality and generality to test our hypotheses by using time and year fixed effects models for controlling unobserved heterogeneity. We found that a patent of blockchain originality was associated with higher firm value. In contrast to the patent of blockchain originality, a patent of blockchain generality was not associated with firm value. However, the effects of the patent of blockchain generality were positively associated with firm value under the consideration of $\mathrm{t}-1$ lagged effects. In contrast to prior studies of patents (e.g., software, computer, drug, electrical, and semiconductor) and firm value, the coefficients for the patent of blockchain originality and $\mathrm{t}-1$ lagged effects for the patent of blockchain generality were relatively small $[11,20,55]$. The minimal coefficients of conventional research prove that a $1 \%$ increase of electrical patent was significantly associated with a $0.147 \%$ increase in a firm's Tobin's q. In contrast to the prior research, a $1 \%$ increase of a patent of blockchain originality was significantly associated with a $0.059 \%$ increase in a firm's Tobin's q and 1\% increase of t- 1 lagged patent of blockchain generality was significantly associated with a $0.018 \%$ increase in a firm's Tobin's q. This indicates that the patent of blockchain is as sustainable for increasing firm value as the conventional patents. However, if we consider the nature of firms by industry, the coefficients for the blockchain patents are similar to prior research. Specifically, 
a $1 \%$ increase of a patent of blockchain originality was significantly associated with a $0.094 \%$ increase in firms' Tobin's q in the software industry. Unlike the conventional patents, if firms do not have original technology of blockchain, the return value for the patent of blockchain needs time to acquire an actual outcome. Vice versa, if firms have original blockchain technology, stakeholders immediately respond to the value of the patent of blockchain originality because the stakeholders can perceive that sustainability for original technology of blockchain is higher in general. In addition, we found that the effects for a firm's patent of blockchain originality and generality are different by industry. In the software industry, the nature of firms is highly related to the creation of more innovative and original technologies, rather than using conventional technologies for creating new software. Thus, sustainability for original technology of blockchain is more important to increase firm value. However, in the hardware industry, the nature of firms is highly related to the creation of new equipment by providing novel products and services to customers. For this reason, sustainability for creating more innovative products by using other technologies is more important to enhance firm value.

\section{Implications and Conclusions}

\subsection{Theoretical Implications}

We extended prior research related to a firm's patenting and firm value by using real options theory. We found three theoretical implications based on our regressions results.

First, we provided theoretical structure by exploring the relationship between a patent of blockchain and firm value. We used the real option theory that a firm's patents can enhance firm value by decreasing market uncertainty. In particular, we suggest that the patents of blockchains are different from conventional patents (e.g., software, hardware, and information technology) by using the patent of blockchain originality and generality. Although many prior studies have proven the theoretical relationship between patents and firm value, our research is the first study to explore the relationship between the patent of blockchain and firm value by providing novel empirical tests and appropriate theory.

Second, we proved the patent of blockchain originality and t-1 lagged effects for the patent of blockchain generality are significantly and positively associated with firm value in the general market. Based on the results, if firms have original technologies of blockchain, firms can achieve the value for the patent of blockchain originality more rapidly than the patent of blockchain generality. This indicates that firms need to allow time for applying extant technologies for increasing the value of a patent of blockchain.

Third, we proved that the sustainable value for the patent of blockchain is differently associated with the nature of firm's characteristics. To the software industry, the patent of blockchain originality is only sustainable for increasing firm value. This indicates that the nature of firms is highly associated with creating original technologies rather using extant technologies. Vice versa, in the hardware industry, the patent of blockchain generality is only sustainable for increasing firm value. This indicates that the nature of firms is highly associated with creating new products and services based on extant technologies.

\subsection{Practical Implications}

Our results and findings provide some practical implications. First, the impact for the patent of blockchain is positively associated with firm value based on originality and lagged effects of generality. Although some managers hold a negative view of the investment in developing the patent of blockchain, we provide novel empirical evidence that the patent of blockchain can contribute to increasing firm value. Second, our study findings can prove how firms can maximize the value for developing the patent of blockchain. In software firms, practitioners should focus on developing original technology of blockchain. Although some managers could have positive insights from using a combination of technologies, the effects of the patent of blockchain originality are more important to maximize their 
firm value in the software industry. Vice versa, in hardware firms, practitioners should focus on the combining of technologies to apply other technologies into their products and services. Even for managers who have a positive view of developing original technologies for the patent of blockchain, the effects from the patent of blockchain generality are more important to maximize firm value in hardware industry.

\subsection{Conclusions}

Our study provides novel results for the relationship between a firm's patent of blockchain and firm value. We concluded that a firm's patent of blockchain originality and $\mathrm{t}-1$ lagged effects for a patent of blockchain generality can increase firm value by using the real options theory. We argue that firm's patent of blockchain can affect firm value differently by industry. In contrast to conventional patents, the technology of blockchain is a new emerging technology and the value for the patent of blockchain has not been clearly explored. Thus, we built robust estimation models based on the patent of blockchain originality and generality. We found that firms can sustainably increase their firm value by acquiring the patent of blockchain. Furthermore, we split our sample by industry to test the sustainability value for the patent of blockchain and firm value in the software and hardware industries. We found that the sustainability value for the patent of blockchain originality was positively and exclusively associated with software industry. Vice versa, the sustainability value for the patent of blockchain generality was positively and exclusively associated with the hardware industry. Although we suggest that a firm's patent of blockchain originality and t-1 lagged effects for a firm's patent of blockchain generality significantly increase firm value, we have some limitations. Our sample data do not include startup and private firms. If the firm's financial data are available, we can consider these firms in future research. In addition, although the patent of blockchain can affect non-IT firms, our results only include IT-based firms. Future research should examine whether non-IT firms' patents of blockchain affect firm value or not.

Author Contributions: H.K. and J.K. have given research ideas and constructed the draft paper; K.J. revised the draft paper and built robust estimation models. J.H. supervised the whole work and provided business insights from the estimation results. All authors have read and agreed to the published version of the manuscript.

Funding: This research received no external funding.

Acknowledgments: This study is partially supported by Korea University Business School Research Grant.

Conflicts of Interest: The authors declare no conflict of interest.

\section{Appendix A}

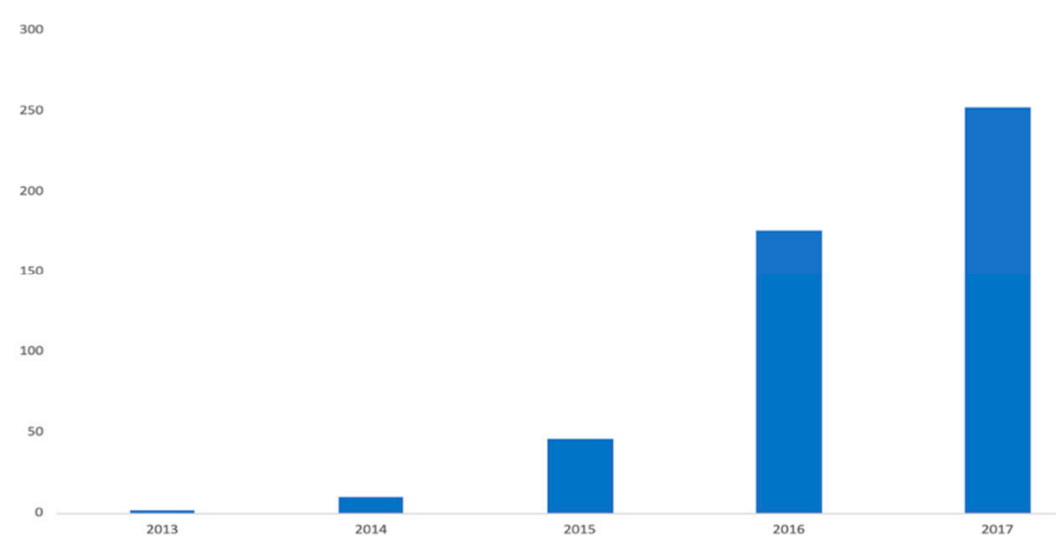

Figure A1. Total numbers for a patent of blockchain in the United States from 2013 to 2017. 


\section{References}

1. Swan, M. Anticipating the Economic Benefits of Blockchain. Technol. Innov. Manag. Rev. 2017, 7, 6-13. [CrossRef]

2. Yli-Huumo, J.; Ko, D.; Choi, S.; Park, S.; Smolander, K. Where is current research on blockchain technology?-A systematic review. PLoS ONE 2016, 11, e0163477. [CrossRef] [PubMed]

3. Catalini, C.; Gans, J.S. Some Simple Economics of the Blockchain; 0898-2937; National Bureau of Economic Research: Cambridge, MA, USA, 2016.

4. Dinh, T.N.; Thai, M.T. AI and Blockchain: A Disruptive Integration. Computer 2018, 51, 48-53. [CrossRef]

5. Mattila, J. The Blockchain Phenomenon-The Disruptive Potential of Distributed Consensus Architectures; ETLA Working Papers; ETLA: Helsinki, Finland, 2016.

6. Lui, A.K.; Ngai, E.W. The Long Term Effect of Blockchain Adoption on Firm Value. In Proceedings of the twenty-fifth Americas Conference on Information Systems, Cancun, Mexico, 15-17 August 2019.

7. Carson, B.; Romanelli, G.; Walsh, P.; Zhumaev, A. Blockchain beyond the Hype: What Is the Strategic Business Value; McKinsey \& Company: Melbourne, Australia, 2018; pp. 1-13.

8. Guo, A. Blockchain receipts: Patentability and admissibility in court. Chi. Kent J. Intell. Prop. 2016, 16, 440.

9. Hussinger, K.; Schwiebacher, F. The Market Value of Technology Disclosures to Standard Setting Organizations. Ind. Innov. 2015, 22, 321-344. [CrossRef]

10. Hall, B.H.; Jaffe, A.; Trajtenberg, M. Market value and patent citations. RAND J. Econ. 2005, 36, 16-38.

11. Chung, S.; Animesh, A.; Han, K.; Pinsonneault, A. Software Patents and Firm Value: A Real Options Perspective on the Role of Innovation Orientation and Environmental Uncertainty. Inf. Syst. Res. 2019, 30, 1073-1097. [CrossRef]

12. Fernandez-Vazquez, S.; Rosillo, R.; De La Fuente, D.; Priore, P. Blockchain in FinTech: A Mapping Study. Sustainability 2019, 11, 6366. [CrossRef]

13. Zhao, Q.; Tsai, P.-H.; Wang, J.-L. Improving Financial Service Innovation Strategies for Enhancing China's Banking Industry Competitive Advantage during the Fintech Revolution: A Hybrid MCDM Model. Sustainability 2019, 11, 1419. [CrossRef]

14. Gans, J.S.; Hsu, D.H.; Stern, S. When Does Start-up Innovation Spur the Gale of Creative Destruction? 0898-2937; National Bureau of Economic Research: Cambridge, MA, USA, 2000.

15. Andries, P.; Faems, D. Patenting Activities and Firm Performance: Does Firm Size Matter? J. Prod. Innov. Manag. 2013, 30, 1089-1098. [CrossRef]

16. Cockburn, I.M.; MacGarvie, M.J. Entry and Patenting in the Software Industry. Manag. Sci. 2011, 57, 915-933. [CrossRef]

17. Blind, K.; Cremers, K.; Mueller, E. The influence of strategic patenting on companies' patent portfolios. Res. Policy 2009, 38, 428-436. [CrossRef]

18. Grimaldi, M.; Cricelli, L.; Rogo, F. Valuating and analyzing the patent portfolio: The patent portfolio value index. Eur. J. Innov. Manag. 2018, 21, 174-205. [CrossRef]

19. Harrigan, K.R.; Di Guardo, M.C.; Marku, E. Patent value and the Tobin's q ratio in media services. J. Technol. Transf. 2018, 43, 1-19. [CrossRef]

20. Shane, H.; Klock, M. The Relation Between Patent Citations and Tobin's Q in the Semiconductor Industry. Rev. Quant. Finance Account. 1997, 9, 131-146. [CrossRef]

21. Coffie, C.P.K.; Zhao, H.; Mensah, I.A. Panel Econometric Analysis on Mobile Payment Transactions and Traditional Banks Effort toward Financial Accessibility in Sub-Sahara Africa. Sustainability 2020, 12, 895. [CrossRef]

22. Ceccagnoli, M.; Forman, C.; Huang, P.; Wu, D.J. Cocreation of Value in a Platform Ecosystem! The Case of Enterprise Software. MIS Q. 2012, 36, 263. [CrossRef]

23. Lin, C.; Chang, C.-C. A patent-based study of the relationships among technological portfolio, ambidextrous innovation, and firm performance. Technol. Anal. Strat. Manag. 2015, 27, 1-19. [CrossRef]

24. Fichman, R.G. Real Options and IT Platform Adoption: Implications for Theory and Practice. Inf. Syst. Res. 2004, 15, 132-154. [CrossRef]

25. Balasubramanian, N.; Sivadasan, J. What Happens When Firms Patent? New Evidence from U.S. Economic Census Data. Rev. Econ. Stat. 2011, 93, 126-146. [CrossRef] 
26. Gatteschi, V.; Lamberti, F.; DeMartini, C.; Pranteda, C.; Santamaria, V. To Blockchain or Not to Blockchain: That Is the Question. IT Prof. 2018, 20, 62-74. [CrossRef]

27. Zhao, J.L.; Fan, S.; Yan, J. Overview of business innovations and research opportunities in blockchain and introduction to the special issue. Financ. Innov. 2016, 2, 12. [CrossRef]

28. Drobyazko, S.; Makedon, V.; Zhuravlov, D.; Buglak, Y.; Stetsenko, V. Ethical, technological and patent aspects of technology blockchain distribution. J. Leg. Ethical Regul. Issues 2019, 22.

29. Ko, T.; Lee, J.; Ryu, D. Blockchain Technology and Manufacturing Industry: Real-Time Transparency and Cost Savings. Sustainability 2018, 10, 4274. [CrossRef]

30. Hall, B.H.; Jaffe, A.B.; Trajtenberg, M. The NBER Patent Citation Data File: Lessons, Insights and Methodological Tools; 0898-2937; National Bureau of Economic Research: Cambridge, MA, USA, 2001.

31. Benner, M.J.; Tushman, M. Process Management and Technological Innovation: A Longitudinal Study of the Photography and Paint Industries. Adm. Sci. Q. 2002, 47, 676. [CrossRef]

32. Bhojraj, S.; Lee, C.M.C.; Oler, D.K. What's My Line? A Comparison of Industry Classification Schemes for Capital Market Research. J. Account. Res. 2003, 41, 745-774. [CrossRef]

33. Kohli, R.; Devaraj, S.; Ow, T.T. Does Information Technology Investment Influences Firm's Market Value? The Case of Non-Publicly Traded Healthcare Firms. Mis Q. 2012, 36, 1145-1163. [CrossRef]

34. Xue, L.; Ray, G.; Sambamurthy, V. Efficiency or Innovation: How Do Industry Environments Moderate the Effects of Firms' IT Asset Portfolios? MIS Q. 2012, 36, 509. [CrossRef]

35. Bharadwaj, A.S.; Bharadwaj, S.G.; Konsynski, B.R. Information Technology Effects on Firm Performance as Measured by Tobin's q. Manag. Sci. 1999, 45, 1008-1024. [CrossRef]

36. Kaen, F.R.; Baumann, H.D. Firm Size, Employees and Profitability in U.S. Manufacturing Industries. SSRN Electron. J. 2003. [CrossRef]

37. Baber, W.R.; Fairfield, P.M.; Haggard, J.A. The effect of concern about reported income on discretionary spending decisions: The case of research and development. Account. Rev. 1991, 66, 818-829.

38. García-Manjón, J.V.; Romero-Merino, M.E. Research, development, and firm growth. Empirical evidence from European top R\&D spending firms. Res. Policy 2012, 41, 1084-1092.

39. Hitt, L.M.; Brynjolfsson, E. Productivity, Business Profitability, and Consumer Surplus: Three Different Measures of Information Technology Value. MIS Q. 1996, 20, 121. [CrossRef]

40. Petter, S.; Rai, D.S. Specifying Formative Constructs in Information Systems Research. MIS Q. 2007, $31,623$. [CrossRef]

41. Kock, N.; Texas A\&M International University; Lynn, G. Stevens Institute of Technology Lateral Collinearity and Misleading Results in Variance-Based SEM: An Illustration and Recommendations. J. Assoc. Inf. Syst. 2012, 13, 546-580.

42. Prunier, J.G.; Colyn, M.; Legendre, X.; Nimon, K.F.; Flamand, M.C. Multicollinearity in spatial genetics: Separating the wheat from the chaff using commonality analyses. Mol. Ecol. 2015, 24, 263-283. [CrossRef] [PubMed]

43. Gnyawali, D.R.; Fan, W.; Penner, J. Competitive Actions and Dynamics in the Digital Age: An Empirical Investigation of Social Networking Firms. Inf. Syst. Res. 2010, 21, 594-613. [CrossRef]

44. Hausman, J.; McFadden, D. Specification Tests for the Multinomial Logit Model. J. Econ. Soc. 1984, 52, 1219. [CrossRef]

45. Wooldridge, J.M. Econometric Analysis of Cross Section and Panel Data; MIT Press: Cambridge, MA, USA, 2002; Volume 108.

46. Drukker, D.M. Testing for Serial Correlation in Linear Panel-data Models. Stata J. Promot. Commun. Stat. Stata 2003, 3, 168-177. [CrossRef]

47. Bascle, G. Controlling for endogeneity with instrumental variables in strategic management research. Strat. Organ. 2008, 6, 285-327. [CrossRef]

48. Geroski, P.A.; Machin, S.J.; Walters, C.F. Corporate growth and profitability. J. Ind. Econ. 1997, 45, 171-189. [CrossRef]

49. Elsayed, K.; Paton, D. The impact of environmental performance on firm performance: Static and dynamic panel data evidence. Struct. Chang. Econ. Dyn. 2005, 16, 395-412. [CrossRef]

50. Sequeira, T.N.; Nunes, P.M. Does tourism influence economic growth? A dynamic panel data approach. Appl. Econ. 2008, 40, 2431-2441. [CrossRef] 
51. Arellano, M.; Bover, O. Another look at the instrumental variable estimation of error-components models. J. Econ. 1995, 68, 29-51. [CrossRef]

52. Blundell, R.; Bond, S. Initial conditions and moment restrictions in dynamic panel data models. J. Econ. 1998, 87, 115-143. [CrossRef]

53. Ahn, S.C.; Gadarowski, C. Small sample properties of the GMM specification test based on the Hansen-Jagannathan distance. J. Empir. Finance 2004, 11, 109-132. [CrossRef]

54. Hansen, L.P.; Singleton, K.J. Generalized Instrumental Variables Estimation of Nonlinear Rational Expectations Models. J. Econ. Soc. 1982, 50, 1269. [CrossRef]

55. Lin, B.-W.; Chen, C.-J.; Wu, H.-L. Patent portfolio diversity, technology strategy, and firm value. IEEE Trans. Eng. Manag. 2006, 53, 17-26.

(C) 2020 by the authors. Licensee MDPI, Basel, Switzerland. This article is an open access article distributed under the terms and conditions of the Creative Commons Attribution (CC BY) license (http://creativecommons.org/licenses/by/4.0/). 